\title{
Effect of Leptin, Pituitary Transcription Factor and Luteinizing Hormone Receptor Genes Polymorphisms on Reproductive Traits and Milk Yield in Holstein Cattle
}

\author{
Mayra Alejandra Cañizares-Martínez ${ }^{1,2}$ \\ https://orcid.org/0000-0001-9086-9401
}

\section{Gaspar Manuel Parra-Bracamonte ${ }^{3}$ \\ https://orcid.org/0000-0002-9327-2042}

José Candelario Segura-Correa ${ }^{2}$

https://orcid.org/0000-0003-1329-9948

\author{
Juan Gabriel Magaña-Monforte ${ }^{2^{*}}$ \\ https://orcid.org/0000-0002-0128-6747
}

${ }^{1}$ Centro de Investigación y de Estudios Avanzados del Instituto Politécnico Nacional, Departamento de Recursos del Mar, Merida, Yucatan, Mexico; 'Universidad Autónoma de Yucatán, Facultad de Medicina Veterinaria y Zootecnia, Merida, Yucatan, Mexico; ${ }^{3}$ Centro de Biotecnología Genómica, Instituto Politécnico Nacional, Reynosa, Tamaulipas, Mexico.

Editor-in-Chief: Paulo Vitor Farago

Associate Editor: Cheila Roberta Lehnen

Received: 2019.10.22; Accepted: 2021.02.23.

*Correspondence: jmagana@correo.uady.mx; Tel.: +52 9997467160 (J.G.M.M.).

\section{HIGHLIGHTS}

- The CC genotype of the LEP gene decreases 28.71 days of the calving to conception interval.

- The AA genotype of the Pit-1 gene decreases 41.36 days the age at first calving.

- The CC genotype of the LEP gene decreases 13.62 days the calving interval.

- $\quad$ A59V and Hinfl loci are candidate SNPs to be validated in marker assisted programs.

Abstract: The aim of this study was to estimate allelic and genotypic frequencies of markers in the leptin (LEP), pituitary transcription factor (PIT-1) and luteinizing hormone receptor (LHR) genes and evaluate their effects on reproductive traits and milk yield of Holstein cattle. Data from 147 cows from department of Francisco Morazán, Honduras, were collected and PCR-Restriction Fragment Length Polymorphism (RFLP) assays were performed to characterize the PIT-1-Hinfl, LEP-A59V and LHR-rs41256848 polymorphisms. To estimate the effect of genotypes on reproductive traits and milk yield fixed and mixed linear models were fitted. The frequencies of the genotypes CC, CT and TT of A59V, AA, AB and BB of Hinfl, and CC, CG and GG of rs 41256848 were $0.46,0.33$ and, $0.21 ; 0.09,0.32$ and 0.58 ; and $0.37,0.61$ and 0.02 , respectively. The genotypes of LEP and LHR showed deviations from Hardy-Weinberg equilibrium. The A59V polymorphism was significantly associated with the calving to conception interval $(\mathrm{CCl})(p=0.01)$, being the $\mathrm{C}$ allele 
favorable. The Hinfl and rs41256848 polymorphism were significantly associated $(p=0.08$ and $p=0.04)$ with age to first calving (AFC), being the $A$ and $G$ the alleles favorable associated, respectively. The results suggest that LEP, PIT and LHR polymorphisms can probably act as candidate to be used in marker-assisted selection for AFC and $\mathrm{CCl}$ traits.

Keywords: dairy cattle; PCR-RFLP; reproduction; SNP.

\section{INTRODUCTION}

The specialized dairy farming in Honduras is based mainly in Holstein cattle (Bos taurus), where the reproductive management, included insemination with semen from the United States and Canada, mostly considering genetic merit for milk yield in sire selection. This breed is worldwide appreciated by its dairy productive ability; however, this breed has decreased the mean performance of their reproductive traits because of the antagonism due to the high genetic selection towards productive characteristics, which comprise the profitability in dairy production systems and the replacement of animals [1].

One way to improve the reproductive performance of cows is to implement genetic selection programs supported by molecular markers. This strategy may allow to use a proportion of the genetic variance favorably associated with the trait of interest [2] to increase the reproductive efficiency. In the same way, these molecular techniques characterize genetic diversity in the Holstein population, to improve evolutionary processes and adaptation to variable environmental situations [3,4] (e.g. climate change), by example, using genomic introgression that simultaneously might improve both adaptation and production depending on the genetic correlation and considering the rate of inbreeding [5].

Currently, the most widely used markers are single nucleotide polymorphisms (SNPs) due to their high frequency and dispersion in the genome. These polymorphisms are changes in the DNA sequence that are manifested in more than $1 \%$ of the population and can be associated favorably or unfavorably with any particular trait[6]. By identifying these changes, it is possible to establish the genetic diversity and variability present in local populations and optimize the targeting of selection programs even from juvenile stages of animals[7].

These SNPs markers are now being extensively used in animal breeding selection programs to reduce generational intervals and increase the accuracy of genetic evaluations of economically important traits, especially those with low heritability [8]. Additionally, the candidate gene approach [9] takes advantage of previous information on the function, activity, and location from genome sequencing data of some candidate, to determine significant variants associated to an economical relevant trait of interest, revealing the genetic architecture of some productive traits and hence, has been proposed for marker-assisted selection in genetic improvement programs of cattle. Some studies have identified SNPs present in the Leptin (LEP), Pituitary (PIT-1) and Luteinizing Hormone Receptor (LHR) genes with significant effects on some reproductive traits $[10,11,12]$.

The LEP gene encodes 167 amino acids that make up a polypeptide hormone that plays metabolic functions and intervenes in the neuroendocrine system that regulates gonadal functions, modulates the action of the insulin and of the insulin-like growth factors (IGFs). The SNP A59V (rs29004508), given by a change $\mathrm{C}>\mathrm{T}$ in the 3100 position of exon 3 , has been strongly associated with age at first service, age at first calving (AFC), calving interval (Cl) and numbers of services per conception (NSC) [13].

The PIT1 gene belongs to the family of transcription factors homeo-domain, which activates the expression of the prolactin (PRL) and the growth hormone $(\mathrm{GH})$. It also participates in the signaling processes of the development of the pituitary gland, mammary gland, growth and the expression of the proteins in milk. The Hinfl polymorphism (position A1256G, exon 6) has been favorably associated with longer open days, greater growth and development, and favorable for quality and milk production [14,15].

The LHR gene synthesizes a protein that allows the action of the luteinizing hormone (LH) when it binds to it and plays a fundamental role in folliculogenesis. Its expression in the cells of the granulose of the dominant follicle is essential in the final stages of follicular growth, at the end of the oocyte maturation, ovulation and the luteinization of the follicular wall. Some studies have associated the SNP rs41256848 (position G1410T, exon 11) with reproductive traits such as decrease CI, NSC and favorable for superovulation treatments $[16,17]$.

Therefore, these genes are candidates to identify markers favorably associated with traits of economic importance, particularly for their fundamental role in the reproductive, developmental aspect, and adequate energy in each of the biological processes involved in the growth of organisms. Hence, the objectives of this 
study were to estimate the allelic and genotypic frequencies of markers in LEP, PIT-1 and LHR candidate genes, and to assess their effect on reproductive traits and milk yield of Holstein cattle from Honduras.

\section{MATERIALS AND METHODS}

\section{Animals and phenotypic data}

Data from 347 lactations and samples from 147 Holstein cows in the months of July to August 2016 were obtained from the "Escuela Agrícola Panamericana", El Zamorano (EAP) and the farm "El Carreto" located in the department of Francisco Morazán, in the central-eastern Honduras. Average age of cows was 4 yearsold. The nutritional management of the animals in both dairy farms consisted in the confinement of cows during the dry season, with balanced feeding, and during the rainy season the animals were maintained in rotational grazing with native forages Panicum maximum (cv. Tobiatá, Mombasa, Guinea), Cynodon nlemfluensis (Star), and supplemental feeding with corn silage (Zea mays) and sorghum (Sorghum spp.).

Cow records were captured in the VAMPP $\AA$ software, from which the variables of interest were age at first calving (AFC, days), calving interval in days $(\mathrm{Cl}$, days), calving to conception interval (CCl), number of service per conception (NSC, times) and milk yield adjusted to 305 days (MP305, kg) (Table 1).

Table 1. Descriptive statistics for analyzed traits considered in the study.

\begin{tabular}{ccccccccc}
\hline Traits & N & Mean & Median & Min & Max & CV & SD & SE \\
\hline AFC (days) & 145 & 908.3 & 887 & 518 & 2113 & 21.62 & 196.4 & 16.31 \\
MP305 (kg) & 266 & 5377.90 & 5380 & 1974 & 9720 & 25.66 & 1380.10 & 84.62 \\
CCI (days) & 254 & 153.36 & 133 & 41 & 560 & 58.14 & 89.17 & 5.59 \\
NSC (times) & 320 & 2.24 & 2 & 1 & 10 & 64.12 & 1.44 & 0.08 \\
Cl (days) & 192 & 435.01 & 417 & 309 & 727 & 18.89 & 82.16 & 5.93 \\
\hline
\end{tabular}

n: number of data, Min: Minimum value, Max: Maximum value, CV: Coefficient of variation, SD: Standard deviation,

SE: Standard error.

\section{Genotyping}

DNA was extracted from hair follicles of the tassel of the tail ( 60 follicles from each cow), according to the protocol of the Genelute Mammalian Genomic DNA Kit (Sigma-Aldrich, St Louis, Mo, USA). The quality of the DNA was assessed by $1.5 \%$ agarose gel and quantified by means of the Kodak Molecular Imaging Software Standard Edition V5.0.

\section{DNA Amplification by RFLP-PCR}

The RFLP-PCR assays were designed using specific primers for each gene, according to the sequences located in the GenBank. The enzymes for the polymorphisms of the LEP and PIT1 genes were found in the literature and for the polymorphism of LHR gene was identified by means of Watcut, an online tool from the University of Waterloo [18] (Table 2).

Table 2. Primers and enzymes used for each gene according to sequence reported in National Center for Biotechnology Information (NCBI).

\begin{tabular}{ccclcc}
\hline Gene & GenBank & Enzyme & \multicolumn{1}{c}{ Primers } & Size & Reference \\
\hline PIT1 & EF090615.2 & Hinf1 & $\begin{array}{l}\text { Fw5'AAACCATCATCTCCCTTCTT3' } \\
\text { Rv5'AATGTACAATGTCCTTCTGAG3' }\end{array}$ & 451pb & Woollard et al.[19] \\
LEP & U50365.1 & Hphl & $\begin{array}{l}\text { FW 5'GGG AAG GGC AGA AAG ATA G3' } \\
\text { RV 5'-TGG CAG ACTGTTGAG GATC3' }\end{array}$ & 331pb & Haegeman[20] \\
LHR & NM_174381.1 & Tsp451 & $\begin{array}{l}\text { FW 5'CAAACTGACAGTCCCCCGCTTT3' } \\
\text { RV 5'CCTCCGAGCATGACTGGATGGC3' }\end{array}$ & 303pb & Milazzotto et al.[21] \\
\hline
\end{tabular}

All PCR reactions were carried out in a volume of $15 \mu \mathrm{L}$ with $25 \mathrm{ng}$ of DNA, $1 \mathrm{X}$ reaction buffer, $1 \mathrm{mM}$ $\mathrm{MgCl} 2,0.4 \mathrm{mM}$ of each dNTP; $0.3 \mu \mathrm{M}$ primers and 1 UTaq DNA polymerase and were processed in MJ Research thermal cycler. 
Touchdown PCR conditions (TD) began with the denaturation at $95^{\circ} \mathrm{C}$ for 5 minutes, followed by 5 cycles of incubation at $95 \mathrm{C}$ for $45 \mathrm{sec}$ alignment to $62^{\circ} \mathrm{C}$ (decreasing $2{ }^{\circ} \mathrm{C}$ every cycle) for $45 \mathrm{sec}$ and an extension at $72{ }^{\circ} \mathrm{C}$ for $45 \mathrm{sec}$. Subsequently gave an initial denaturation at $95 \mathrm{C}$ for 5 minutes, followed by 30 cycles at $95 \mathrm{C}$ for 45 seconds, alignment to $55 \mathrm{C}$ (for LEP and Pit-q) or $60 \mathrm{C}$ (for LHR) for $45 \mathrm{sec}$, and extension end for 10 minutes at $72 \stackrel{\circ}{\circ}$.

The RFLP reactions were carried out in a volume of $15 \mu \mathrm{L}$ with 1 unit of enzyme for each gene. The temperature and time of digestion for the enzymes Hinf1 and $\mathrm{Hphl}$ were $37^{\circ} \mathrm{C}$ for 8 hours and for the enzyme Tsp451 was $65^{\circ} \mathrm{C}$ for 1 hour.

For evaluation, the PCR products were visualized on $1.5 \%$ agarose gel for 45 minutes and the digestions RFLP were visualized on $2.5 \%$ agarose gels after of 2 to 4 hours according to the product. The size M50 was used as ladder.

\section{Statistical analysis}

The allelic and genotypic frequencies of each polymorphism and the Hardy-Weinberg (HW) equilibrium were estimated using GENEPOP software version 4.2 [22]. To estimate the effect of the genotypes on the $\mathrm{Cl}$ and $\mathrm{CCl}$, a repeated measure mixed model was fitted, including a Compound Symmetry (CS) covariance arrangement using the MIXED procedure of SAS [23]. The model fitted was:

$$
Y_{i j k l m n o}=\mu+G_{i}+H_{j}+S_{k}+N_{l}+A_{m}+I D_{n}+\epsilon_{i j k l m n o}
$$

Where: $Y_{i j k l m n o}$, is the ijklm-observation of the analyzed variable $(\mathrm{Cl}, \mathrm{CCl}$ and NSC) of the o-th cow; $\mu$ is the overall mean, $G_{i}$ corresponds to the i-th genotype of PIT1, LEP, LHR, $H_{j}$ corresponds to the j-th herd, $S_{k}$ is the k-th season of calving, $N_{l}$ is the l-th number of calving, $A_{m}$ corresponds to the m-th year of calving, $I D$ corresponds to the $\mathrm{n}$-th sire effect and $\epsilon_{i j k l m n o}$ is the random residual error. The number of calving of the cow was grouped as those with one or more than one calving. Year of calving was grouped in those happening before 2011 and those calving after 2012. To approximate them to normality, the data were transformed using the logarithm Base 10 function, except for NSC. A general linear model that described AFC and MP305 included the fixed effects of herd, birth season, year of calving and genotype. Data of age at first calving were also approximated to the normal distribution taken the reciprocal of AFC (1/IFC).

To determine the influence of the genotype, the methodology proposed by Clempson and coauthors [13] was used, where homozygous effects were estimated as deviation of the heterozygous genotype, taking as reference the estimated value of the least squares means differences. T-Student test and the standard errors of the differences were calculated for each of the means tested. Given its low frequency, the effect of the TT genotype of the polymorphism rs41256848 was not considered.

\section{RESULTS}

\section{Allelic and genotypic frequencies}

All samples amplified for each gene (PIT-1, LEP, and LHR). The alleles A and B were identified for the PIT-1 gene (Figure 1A); the B allele showed two bands (244 and $207 \mathrm{bp}$ ) and the presence of a single band allowed the identification of allele $A$, due to the absence of the restriction site for the enzyme Hinfl. The number of individuals for genotypes $A A, A B$ and $B B$ were 13,48 and 86 , respectively.

The alleles $\mathrm{C}$ and $\mathrm{T}$ were identified through RFLP for the LEP-Hphl polymorphism, showing an electrophoretic pattern of two bands in the presence of the restriction site for the mutated allele $\mathrm{T}$ (311 and $20 \mathrm{pb}$ ), and in the absence of the place of recognition of the enzyme the allele $C(331 \mathrm{pb})$ (Figure 1B). The number of individuals for genotypes CC, CT and TT were 67, 49 and 31, respectively.

The alleles $\mathrm{G}$ and $\mathrm{T}$, identified by the enzyme Tsp451, showed an electrophoretic pattern not previously reported for LHR gene (Figure 1C). In the presence of the recognition site of the enzyme, mutated allele T $(228$ and $75 \mathrm{pb})$ and in its absence the $\mathrm{G}$ allele $(303 \mathrm{pb})$ were identified. The number of individual for genotypes GG, GT and TT were 54, 91 and 2, respectively. The allelic and genotypic frequencies and HW test $p$ values of the three polymorphisms are shown in Table 3.

The results showed significant differences between the found and expected genotypic frequencies ( $P$ $<0.05$ ) in the LEP and LHR genes, indicating that the study population was not in equilibrium Hardy-Weinberg. The PIT1 genotypic frequencies were in genetic equilibrium. 


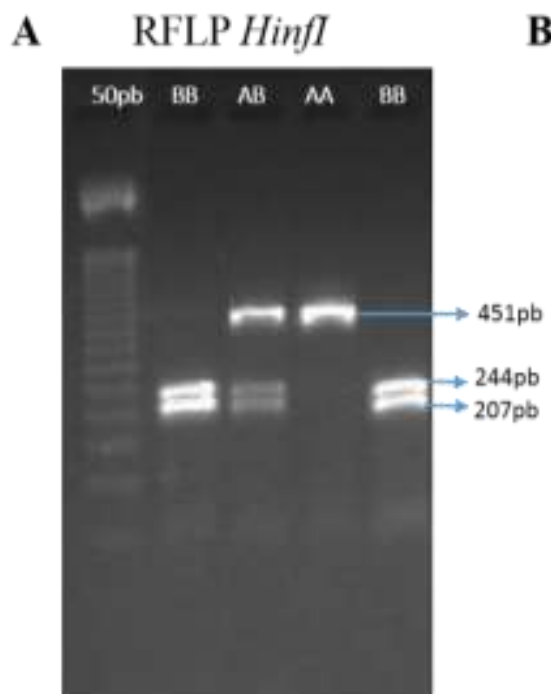

B RFLP HphI

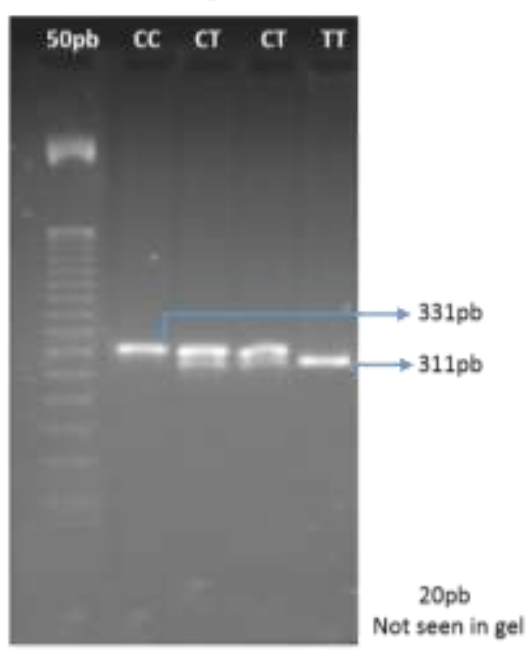

C RFLP Tsp 451

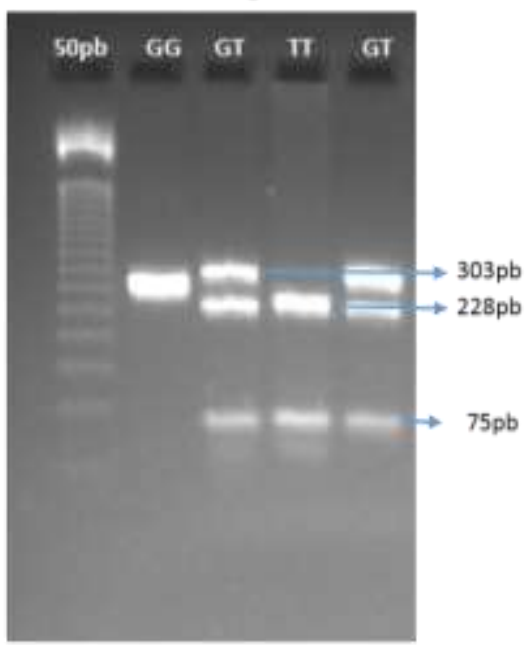

Figure 1. Electrophoretic pattern of each of polymorphisms. In the upper part of the images are presented the genotype. Amplicon size are indicated in the right side of the images. (A) The 1.5\% agarose gel from PIT-1 gene, allele A $451 \mathrm{pb}$ and allele B (244pb, 207pb); (B) 2.5\% agarose gel from LEP gene, allele C 331pb and allele T (311pb, 20pb); (C) 1.5\% agarose gel from LHR gene, allele G $303 \mathrm{pb}$ and allele $T(228 \mathrm{pb}, 75 \mathrm{pb})$. In the first lane of each gels it is showed the 50 bp ladder reference marker.

Table 3. Allelic and genotypic frequencies of polymorphisms in assessed candidate genes.

\begin{tabular}{lcccccc}
\hline Loci & \multicolumn{2}{c}{ Allelic frequencies } & \multicolumn{3}{c}{ Genotypic frequencies } & HW $^{1}$ \\
\hline \multirow{2}{*}{ PIT-1 (Hinf) } & $\mathrm{A}$ & $\mathrm{B}$ & $\mathrm{AA}$ & $\mathrm{AB}$ & $\mathrm{BB}$ & \multirow{2}{*}{$\mathrm{NS}$} \\
& 0.25 & 0.75 & 0.09 & 0.33 & 0.58 & \\
\hline \multirow{2}{*}{ LEP (A59V) } & $\mathrm{C}$ & $\mathrm{T}$ & $\mathrm{CC}$ & $\mathrm{CT}$ & $\mathrm{TT}$ & \multirow{2}{*}{0.003} \\
\hline \multirow{2}{*}{ LHR (rs41256848) } & 0.62 & 0.38 & 0.46 & 0.33 & 0.21 & \\
& $\mathrm{G}$ & $\mathrm{T}$ & $\mathrm{GG}$ & $\mathrm{GT}$ & $\mathrm{TT}$ & \multirow{2}{*}{0.000} \\
\hline
\end{tabular}

${ }^{1}$ Hardy-Winberg equilibrium $p$-value: $\mathrm{NS}=\mathrm{P}>0.05$.

\section{Association of the genotypes with milk yield and reproductive traits}

The polymorphism A59V of the LEP gene was significantly associated with $\mathrm{CCl}(p=0.01)$ and the favorable genotype was CC. The CCI decreases 28 days in comparison with the heterozygote CT animals; also, this genotype showed a significant difference in relation to the homozygote TT. For this gene the genotype CC showed a decrease in the amount of NSC and an increase in MP305, however, they do not reach significantly values. In relation to TT cows, can be observed a decrease in AFC respect to the others, even though, this same genotype showed an increase in Cl days (Table 4).

The polymorphism Hinfl of PIT-1 gene showed a trend of association with AFC ( $p=0.08)$. The favorable genotype for this trait were AA since the AFC decreased by 38 days compared to the mean of heterozygote. For this same genotype, a favorable increase in MP305 can be observed (Table 3) when comparing the values with the heterozygote and homozygote $\mathrm{BB}$, but in NSC and $\mathrm{CCl}$ increase the values, with nonsignificantly differences (Table 4).

In the case of the rs 41256848 polymorphism of the LHR gene, a significant association was found $(p=$ 0.04) with AFC, where the favorable genotype was the homozygote GG since a decrease of 40 days is observed in relation to the mean of the heterozygote genotype. This same genotype was observed favorable for MP305 but unfavorable for $\mathrm{CCl}$, and NSC in comparison with heterozygote animals, although without significant difference. 
Table 4. Means and standard error of the effect of three candidate SNPs on reproductive traits and milk yield in Holstein cattle.

\begin{tabular}{ccccccc}
\hline Loci & Genotype & AFC & CCI & Cl & NSC & MP305 \\
\hline \multirow{2}{*}{ PIT1 (Hinf) } & AA & $813 \pm 34.13^{*}$ & $148 \pm 37.8$ & $417 \pm 27.3$ & $0.92 \pm 0.14$ & $5200 \pm 398$ \\
& AB & $851 \pm 18.03$ & $132 \pm 18.8$ & $437 \pm 29.7$ & $0.76 \pm 0.07$ & $4916 \pm 200$ \\
& BB & $891 \pm 13.03$ & $132 \pm 14.4$ & $417 \pm 21.3$ & $0.68 \pm 0.06$ & $5069 \pm 171$ \\
LEP (A59V) & CC & $871 \pm 15.4$ & $117 \pm 16.4^{*}$ & $417 \pm 31.1$ & $0.66 \pm 0.07$ & $5059 \pm 185.6$ \\
& CT & $871 \pm 18.26$ & $145 \pm 18.84$ & $417 \pm 28.8$ & $0.74 \pm 0.07$ & $5018 \pm 186.3$ \\
LHR & TT & $851 \pm 22.19$ & $145 \pm 21.57$ & $437 \pm 29.6$ & $0.81 \pm 0.08$ & $4953 \pm 229$ \\
(rs41256848) & GG & $851 \pm 17.81^{*}$ & $138 \pm 18.7$ & $427 \pm 31.3$ & $0.73 \pm 0.07$ & $5588 \pm 175.5$ \\
\hline AF: & GT & $891 \pm 13.04$ & $129 \pm 15.3$ & $427 \pm 22.5$ & $0.72 \pm 0.06$ & $5217 \pm 138.6$ \\
\hline
\end{tabular}

AFC: age at first calving (days), Cl: calving interval (days), CCl: calving to conception interval (days), NSC: number of service per conception, and MP305: milk yield adjusted to 305 days $(\mathrm{kg}) .{ }^{*}$ represents the significant difference $p<0.05$.

\section{DISCUSSION}

\section{Allele and genotype frequencies}

The frequency of the A allele of the PIT1- Hinfl polymorphism in Holstein cattle, was higher in this study, in relation to the values reported by Wollard and coauthors.[19], Renaville and coauthors.[24], Hor-Oshima and Barreras-Serrano [25], Yan and coauthors.[26], Zakizadeh and coauthors.[27], Jawasreh and coauthors.[28] and Ozdemir [29]. But the frequency was similar to the values reported by Oprzadek and coauthors. [30], Dybus and coauthors.[31], Vargas and coauthors.[32], Edriss and coauthors.[33], Misriantia and coauthors. [34] and Corrales-Alvarez and coauthors.[11]. In those studies, the frequency of the B allele was greater than that for the A allele, as in this population. It has been reported, in Irani Holstein cattle and Gyr bulls in Brazil, that the allele on homozygous state (BB) could increase the production and quality of milk $[35,36]$.

In the case of A59V polymorphism in the LEP gene, the allelic frequencies found for $C$ and $T$ in this study, are similar to those described by Madeja and coauthors.[37] in Holstein cattle. The frequency of the TT genotype in this population is higher than that reported by Haegeman and coauthors.[20], Liefers and coauthors.[38,39], Almeida and coauthors.[40], Kuling[41], Komisarek[42] and Yazdania and coauthors.[43] with values ranging from 0.02 to 0.09 . This genotype has been positively associated, in Holstein cattle, with somatic cell counts, protein, milk fats and non-return rate of cows[10,41], and in Jersey cattle the genotype (TT) has been associated with lower $\mathrm{Cl}$, NSC and $\mathrm{CCl}$ [39].

In the present study, the allelic and genotypic frequencies for the polymorphism rs41256848 in the LHR gene were different from the frequencies reported in the literature. The frequency of the allele $T$ is greater than that reported by Vasquez[44], but lower than the obtained by Yu and coauthors.[45]. The TT genotype has been favorably associated with a decrease in the calving interval, days at the first service and a longer productive life in Holstein cattle [16,12].

The allelic frequencies differences found in relation to previously mentioned studies in the three evaluated polymorphisms could be associated with the different parental lines, the development and management conditions of the herds, and in particular that Honduras does not have well-established selection programs for dairy cattle in tropical environments. Furthermore, the deviation from Hardy-Weinberg equilibrium for the LEP- A59V and LHR-rs41256848 polymorphism could be possibly due to the gene flow provided by semen importation from United States and Canada. Non-random use of bulls from these countries, subject to selection programs that could have contributed to an increase in the segregation of some alleles, in search of beneficial traits of economic interest. Similarly, since the population sample is small, the stability property is almost non-existent, because the gene frequencies are subject to random fluctuations resulting from the gametic sampling, forming a dispersive process [46], due to a non-random mating with a smaller genepool.

In the case of the SNP in PIT1 gene, the Hardy-Weinberg equilibrium could be attributed to the fact that there have not been specific selection processes for this polymorphism in the parental populations and thus 
stable allele frequencies remain from one generation to the next [46]. A reflection of this pattern is observed in allele frequencies given in Table 3.

\section{Association of the polymorphisms with reproductive traits}

\section{PIT1-Hinfl polymorphism}

AFC reflects the rate of growth of the female and her age at puberty. The significant trend association with the SNP of the PIT-1 gene may be due to the involvement of this gene in the expression of growth hormone. A previous study in Holstein cattle, mentioned that this polymorphism is significantly associated with aspects of growth and development ${ }^{15}$, particularly of the A allele. This allele has also been associated with milk yield, deeper body and angularity of Holstein cows [24,47,11,14,48,49] .

According to this study, selected animals with genotype AA reduced AFC in 38 days and it could favor the increase of MP305 (Table 4). In addition to the above, AFC reduction could result in a greater number of calves and milk yield by year and per life time of cows [50]; in addition to lower production costs and increase productivity of the herd $[51,52]$.

In relation to the others reproductive traits, the genotype AA shows an increasing trend in days of NCS, $\mathrm{CC}$, and $\mathrm{CCl}$ in relation whit other genotypes, although they were not significantly associated in this study; previous research has found this same behavior for $A$ allele [11,32]. On the other hand, the $B$ allele of this gene was not associated with reproductive trait; however, this locus has been reported to have some epistatic effect with TGLA57 and RM95 genes [53], or be in linkage disequilibrium with other loci with favorable effect on reproduction.

\section{LEP-A59V polymorphism}

The polymorphism A59V also known as A80V, C3100T, C1864T, LepHphl or rs29004508 is a mutation non-synonymous because it presents a change of one amino acid (alanine to valine) at position 80 , in a conserved region of the gene LEP [43]. Its association, in this study, with the $\mathrm{Cl}$ may be due to the involvement of this gene in the neuroendocrine system that regulates ovarian functions. It is known that the recipients of this hormone in ruminants are present both in the follicle and in the corpus luteum $[54,55,56]$. A series of studies in mice [57], pigs [58] and cattle [59] have reported the effect of leptin on the improvement of oocytes maturation, in-vitro fertilization rate and the proportion of embryos that develop up to blastocyst stage.

There are two theories about the participation of leptin in ovulation, the first suggests that during the postpartum period, most cows are in a negative energy balance and low levels of Leptin at this time may be associated with reduced secretion of Gonadotropin, which would prolong the interval until the first ovulation [60]. Supporting this theory, it was identified that the administration of exogenous recombinant leptin during postpartum anestrus increases estrogen concentration and follicle stimulating hormone (FSH) levels, aiding in the development of the ovarian follicle, thus accelerating the occurrence of estrus in cows Bali [61, 62].

A second way suggests that high concentrations of leptin increases the concentrations of the growth hormone $(\mathrm{GH})$ that antagonize the effect of insulin-like growth factor (IGF-I) and insulin, decreasing the production of estradiol and interfering in the development of dominant follicles and oocytes maturation [55]. This fact is supported by a study in Holstein- Friesian cows [63] where high concentrations of leptin and low concentrations of IGF-I before and immediately after calving prolonged the $\mathrm{CCl}$ and first service interval in multiparous cows. Similarly, previous studies linked the low concentrations of IGF-I in postpartum cows, with the increase in the time it takes for a cow to resume estrus $[64,65]$. Therefore, if the SNP A59V of the leptin gene can modulate the activity of leptin before and after calving, its action in the follicle and in oocytes could adequately influence conception rates in cows [13].

The CC genotype of the SNP A59V associated to $\mathrm{CCl}$, has also been associated to early AFC and younger age of cows at first service [13,66]. Clempson and coauthors.[13], suggested that this SNP may have a combined effect with other SNPs of this same gene, such as the UASMS1 and A1457G polymorphisms, which have been reported to have significant effects on NSC and CI. In this same sense, this study shows a favorable trend to decrease the NSC and additionally increase the MP305 with this same genotype, although they were not found significantly. 


\section{LHR-rs41256848 polymorphism}

This polymorphism is a non-synonymous mutation generate a change of amino acid of trypsin to cysteine at position 144. In this study, a significant association was found for this SNP with AFC, with the GG genotype being favorable when decreased 40 days in relation to heterozygote. This positive association may be due to the participation of the LHR protein as endogenous ligand of the $\mathrm{LH}$, which by activating its action in the ovarian cells promote follicular maturation, luteinization and ovulation; participating in the process of steroidogenesis, the production of progesterone and the maintenance of the corpus luteum, also [67].

This SNP has previously been associated to reproductive traits, super-ovulation treatments and productive life of cows, in particular with T allele [16,12,17]. In addition, rs41256848, has been shown to have a significant effect on $\mathrm{Cl}$ and days to first service, when evaluated as a haplotype with rs41256850 SNP ${ }^{12}$. In this study, the low frequency of the TT genotype does not allow establishing an association towards traits such as NSC, CC, and CCl.

\section{CONCLUSIONS}

The results of this study indicated that LEP and LHR polymorphism shows favorable effects on interval traits and age at first calving respectively. This evidence suggest this polymorphisms as candidate for markerassisted selection. Some considerations might be done for local Holstein cattle in Honduras, as favorable variation of these candidate gene loci indicates their possible use in marker assisted programs. Further research in assessed genes may fully validate these findings and found new positive variation for reproductive and other economic important traits.

Funding: This work was supported by the Universidad Autónoma de Yucatán and the Instituto Politécnico Nacional.

Acknowledgments: Authors want to thank to the Dairy Cattle Producer Association of Honduras, the Escuela Agrícola Panamericana El Zamorano (EAP) and "El Carreto" farm for the collaborative support. Also, to the Universidad Autónoma de Yucatán and the Centro de Biotecnología Genómica, Instituto Politécnico Nacional, Reynosa-Tamaulipas. First author thank to the Consejo Nacional de Ciencia y Tecnología (CONACYT) for the Ms.C. Scholarship.

Conflicts of Interest: The authors declare that they do not have any conflict of interest.

\section{REFERENCES}

1. Berry DP, Wall E, Pryce JE. Genetics and genomics of reproductive performance in dairy and beef cattle. Animal. 2014 Apr; 8(sup.1):105-21. doi: https://doi.org/10.1017/S1751731114000743.

2. Van Eenennaam AL, Weigel KA, Young AE, Cleveland MA, Dekkers JC. Applied animal genomics: results from the field. Annu. Rev. Anim. Biosci. 2014 Dic;2:105-39. https://doi.org/10.1146/annurev-animal-022513-114119.

3. Parra-Bracamonte G, Sifuentes Rincón A, Reyna R, Arellano W. Avances y perspectivas de la biotecnología genómica aplicada a la ganadería en México. Trop. Subtrop. Agroecosyt. 2011 Dic;14(3):1025-37.

4. Cassell BG. Optimal genetic improvement for the high producing cow. J. Dairy Sci. 2001 Jun;84,E144-50. https://doi.org/10.3168/jds.S0022-0302(01)70208-1

5. Strandén I, Kantanen J, Russo IRM, Orozco-terWengel P, Bruford MW. Genomic selection strategies for breeding adaptation and production in dairy cattle under climate change. Heredity 2019 Mar;123:307-17. https://doi.org/10.1038/s41437-019-0207-1

6. Mohammadabadi MR, Torabi A, Tahmourespoor M, Baghizadeh A, Esmailizadeh A, Mohammadi A. Analysis of bovine growth hormone gene polymorphism of local and Holstein cattle breeds in Kerman province of Iran using polymerase chain reaction restriction fragment length polymorphism (PCR-RFLP). Afr. J. Biotechnol. 2010 Oct;9(41),6848-52. doi: 10.5897/AJB10.799

7. Ebrahimi MTV, Mohammadabadi M, Esmailizadeh A. Using microsatellite markers to analyze genetic diversity in 14 sheep types in Iran. Archiv fuer Tierzucht. 2017 Jul;60(3),183. https://doi.org/10.5194/aab-60-183-2017

8. Nasr MAF, Awad A, El Araby IE. Associations of Leptin and Pituitary-Specific Transcription Factor Genes' Polymorphisms with Reproduction and Production Traits in Dairy Buffalo. Reprod. Domest. Anim. 2016 Jun;51(4):597-603. https://doi.org/10.1111/rda.12726.

9. Zhu M and Zhao S. Candidate gene identification approach: progress and challenges. Int. J. Biol. Sci. 2007 Oct; 3(7): 420-427. http://dx.doi.org/10.7150/ijbs.3.420

10. Komisarek J. Impact of LEP and LEPR gene polymorphisms on functional traits in Polish Holstein-Friesian cattle. Anim. Sci. Pap. Rep. 2010 May; 28: 133-41.

11. Corrales-Álvarez JD, Cerón-Muñoz MF, Cañas-Álvarez JJ, Acevedo-Valladarez C, Sepúlveda-Restrepo JC, CalvoCardona SJ, Moreno-Ochoa M. Estudio del polimorfismo Hinfi del gen Pit-1 y su asociación con características de 
tipo, producción de leche y días abiertos de vacas Holstein en el departamento de Antioquia, Colombia. Actual Biol. $2010 \mathrm{Nov} ; 32$ (93): 139-45.

12. Hastings N, Donn S, Derecka K, Flint AP, Woolliams JA. Polymorphisms within the coding region of the bovine luteinizing hormone receptor gene and their association with fertility traits. Anim. Genet. 2006 Nov;37(6);583-5. https://doi.org/10.1111/j.1365-2052.2006.01532.x

13. Clempson AM, Pollott GE, Brickell JS, Bourne NE, Munce N, Wathes DC. Evidence that leptin genotype is associated with fertility, growth, and milk production in Holstein cows. J. Dairy Sci. 2011 Jul;94(7);3618-28. https://doi.org/10.3168/jds.2010-3626

14. Aytekin İ, Boztepe S. Associations of PIT1gene polymorphism with milk yield and composition traits in brown swiss cattle. J Anim Plant Sci. 2013;23(5);1281-9.

15. Doosti A, Arshi A, Momeni B. Molecular study of PIT1 gene polymorphism in Holstein and Iranian native cattle. Afr J Agric Res. 2011 Sep;6(19);4467-70.

16. Cochran SD, Cole JB, Null DJ, Hansen PJ. Discovery of single nucleotide polymorphisms in candidate genes associated with fertility and production traits in Holstein cattle. BMC Genet. 2013 Jun;14(49):1471-2156. https://doi.org/10.1186/1471-2156-14-49

17. $\mathrm{Yu} Y$, Pang $\mathrm{Y}, \mathrm{Zhao} \mathrm{H}, \mathrm{Xu} \mathrm{X}, \mathrm{Wu} \mathrm{Z}$, An L, Tian J. Association of a missense mutation in the luteinizing hormone/choriogonadotropin receptor gene (LHCGR) with superovulation traits in Chinese Holstein heifers. J Anim Sci Biotechnol. 2012 Nov;3(35). https://doi.org/10.1186/2049-1891-3-35

18. WatCut. 2014. An on-line tool for restriction analysis, silent mutation scanning, and SNP-RFLP analysis [Internet]. [update 2014 April 17; cited March 2021]. Available from: http://watcut.uwaterloo.ca/template.php.

19. Woollard J, Schmitz CB, Freeman AE, Tuggle CK. Rapid communication: Hinfl polymorphism at the bovine Pit-1 locus. J. Anim Sci. 1994 Apr;72:3267.

20. Haegeman A, Van Zeveren A, Peelman LJ. New mutation in exon 2 of the bovine leptin gene. Anim. Genet. 2004 Jul;31:79. https://doi.org/10.1111/j.1365-2052.2000.579-14.x

21. Milazzotto MP, Rahal P, Nichi M, Miranda-Neto T, Teixeira LA, Ferraz JBS, Garcia JF. New molecular variants of hypothalamus-pituitary-gonad axis genes and their association with early puberty phenotype in Bos taurus indicus (Nellore). Livest Sci. 2008 Apr;114(2-3):274-9. https://doi.org/10.1016/j.livsci.2007.05.006

22. Raymond M, Rousset F. 1995. GENEPOP (version 4.6): population genetics software for exact tests and ecumenicism. J. Heredity. 86:248-9. [update 2020 Dic 8; cited March 2021]. Available from: http://genepop.curtin.edu.au/

23. SAS (Statistical Analysis Systems). 2013. Statistical Analysis Systems. SAS® (versión 9.4) para Windows. SAS Institute Inc Cary (North Carolina) 27513 USA.

24. Renaville R, Gengler N, Vrech E, Prandi A, Massart S, Corradini C, Portetelle D. Pit-1 gene polymorphism, milk yield, and conformation traits for Italian Holstein-Friesian bulls. J. Dairy Sci. 1997 Mar;80(12):3431-8. https://doi.org/10.3168/jds.S0022-0302(97)76319-7

25. Hori-Oshima S, Barreras-Serrano A. Relationships between DGAT1 and PIT-1 genes polymorphism and milk yield in Holstein cattle. J. Anim. Sci. 2003 Jun;81:252.

26. Yan LJ, Liu B, Fang XT, Chen H, Zhang RF, Bao B, Zhang HJ. Analysis of POU1F1 gene polymorphisms in Qinchuan cattle and Chinese Holstein cattle. Yi Chuan. 2006 Nov;28(11):1371-5. 10.1360/yc-006-1371. PMID:17098704

27. Zakizadeh S, Reissmann M, Rahimi G, Javaremi AN, Reinecke P, Mirae-Ashtiani SR, Shahrbabak MM. Polymorphism of the bovine POU1F1 gene: allele frequencies and effects on milk production in three Iranian native breeds and Holstein cattle of Iran. Pak. J. Biol. Sci. 2007 Jul;10(15):2575-8. Doi 10.3923/pjbs.2007.2575.2578

28. Jawasreh KI, Awawdeh F, Rawashdeh I, Hejazeen F, Al-Talib M. The allele and genotype frequencies of bovine pituitary specific transcription factor and leptin genes in Jordanian cattle population by using PCR-RFLP. Austral. J. Basic and Appl. Sci. 2009 Apr;3(3),1601-6.

29. Ozdemir M. Determination of PIT-1/HINF1 polymorphism in Holstein and native ear cattle raised as genetic resource in Turkey. J Anim Plant Sci. 2012;22(1):25-8.

30. Oprzadek J, Flisikowski K, Zwierzchowski L, Dymnicki E. Polymorphisms at loci of leptin [LEP], Pit1 and STAT5A and their association with growth, feed conversion and carcass quality in Black-and-White bulls. Anim. Sci. Pap. Rep. 2003 Sep;21(3):135-45.

31. Dybus A, Szatkowska I, Czerniawska-Piatkowska E, Grzesiak W, Wojcik J, Rzewucka E, Zych S. PIT1-Hinfl gene polymorphism and its associations with milk production traits in polish Black-and-White cattle. Arch. Tierz. 2004 Oct;47(6):557-64.

32. Vargas LD, Gana VE, Escudero IF. Pit-1 gene polymorphism in dairy cows from Central Chile. Arch Zootec. 2004;53(202):217-20. 
33. Edriss V, Edriss MA, Rahmani HR., Sayed-Tabatabaei BE. Pit-1 gene polymorphism of Holstein cows in Isfahan Province. Biotechnology. 2008;7(2):209-12.

34. Misrianti R, Sumantri C, Farajallah A. Polymorphism identification of Pit1 gene in indonesian buffaloes (Bubalus bubalis) and Holstein-Friesian cows. Media Peternakan. 2010 Dec;33(3):131. https://doi.org/10.5398/medpet.2010.33.3.131

35. Ahmadi MM, Mirzaei A, Sharifiyazdi H, Hajibemani A, Ghasrodashti AR. Pituitary-specific transcription factor 1 (Pit1) polymorphism and its association on milk production and some reproductive performance in Holstein dairy cows. Rev.Med.Vet. 2015 Nov;166 (5-6):127-31.

36. Mattos KKD, Del Lama SN, Martínez ML, Freitas AF. Association of bGH and Pit-1 gene variants with milk production traits in dairy Gyr bulls. Pesq. agropec. Bras. 2004 Feb;39(2):147-50. http://dx.doi.org/10.1590/S0100204X2004000200007

37. Madeja Z, Adamowicz T, Chmurzynska A, Jankowski T, Melonek J, Switonski M, Strabel T. Short communication: effect of leptin gene polymorphisms on breeding value for milk production traits. J. Dairy Sci. 2004 Nov;87(11):39257. https://doi.org/10.3168/jds.S0022-0302(04)73531-6

38. Liefers SC, Te Pas MFW, Veerkamp RF, Van Der Lende T. Associations between leptin gene polymorphisms and production, live weight, energy balance, feed intake, and fertility in Holstein heifers. J. Dairy Sci. 2002 Jun;85(6):1633-8. https://doi.org/10.3168/jds.S0022-0302(02)74235-5

39. Liefers SC, Te Pas MF, Veerkamp RF, Chilliard Y, Delavaud C, Gerritsen R, van der Lende T. Association of leptin gene polymorphisms with serum leptin concentration in dairy cows. Mamm. Genome. 2003 Sep;14(9):657-63. https://doi.org/10.1007/s00335-003-2275-y

40. Almeida SEM, Almeida EA, Moraes JCF, Weimer TA. Molecular markers in the LEP gene and reproductive performance of beef cattle. J. Anim. Breed. Genet. 2003 Mar;120(2):106-13. https://doi.org/10.1046/j.14390388.2003.00377.x

41. Kulig $\mathrm{H}$. Association between leptin combined genotypes and milk performance traits of Polish Black-and-White cows. Arch. Tierz. 2005 Oct;48:547. https://doi.org/10.5194/aab-48-547-2005

42. Yazdania H, Rahmani HR, Edris MA, Dirandeh E. Association between A59V polymorphism in exon 3 of leptin gene and reproduction traits in cows of Iranian Holstein. Afr. J. Biotechnol. 2010 Sep;9(36):5997-6000.

43. Komisarek J, Antkowiak A. The relationship between leptin gene polymorphisms and reproductive traits in Jersey cows. Pol. J. Vet. Sci. 2007 Dic;10(4):193-7.

44. Vasquez B, Marques A, Seijas G, De La Rosa O, Aranguren J. Detección de polimorfismos en la región codificante del gen receptor de hormona luteinizante mediante análisis de polimorfismo conformacional de cadena simple y secuenciación en bovinos Carora. Revista Científica. 2014 Sep;24(5):428-35.

45. Yu Y, Pang Y, Zhao H, Xu X, Wu Z, An L, Tian J. Association of a missense mutation in the luteinizing hormone/choriogonadotropin receptor gene (LHCGR) with superovulation traits in Chinese Holstein heifers. J Anim Sci Biotechnol. 2012 Nov;3(35):1-5. https://doi.org/10.1186/2049-1891-3-35

46. Falconer D, Mackay T. Introducción a la Genética Cuantitativa. Cuarta ed. ACRIBIA, S.A. Zaragoza España. 1996. 60p.

47. Huang W, Maltecca $\mathrm{C}$, Khatib H. A proline-to-histidine mutation in POU1F1 is associated with production traits in dairy cattle. Anim. Genet. 2008 Sep;39(5):554-7. https://doi.org/10.1111/j.1365-2052.2008.01749.x

48. Heidari M, Azari MA, Hasani S, Khanahmadi A, Zerehdaran S. Effect of polymorphic variants of GH, Pit-1, and $\beta$ LG genes on milk production of Holstein cows. Russ. J. Genet. 2012 Apr;48(4):417-21. https://doi.org/10.1134/S1022795412040060

49. Carsai TC, Balteanu VA, Vlaic A, Cosier V. The polymorphism of pituitary factor 1 (POU1F1) in cattle. Sci. Pap Anim Sci Biotechnol. 2012;45(1):142-6.

50. Salazar-Carranza M, Castillo-Badilla G, Murillo-Herrera J, Hueckmann-Voss F, Romero-Zúñiga JJ. Edad al primer parto en vacas Holstein de lechería especializada en Costa Rica. Agron Mesoam. 2013 Dic;24:233-43.

51. Pirlo G, Miglior F, Speroni M. Effect of age at first calving on production traits and on difference between milk yield returns and rearing costs in Italian Holsteins. J. Dairy Sci. 2000 Mar;83(3):603-8. https://doi.org/10.3168/jds.S00220302(00)74919-8

52. Radostits O. Herd heath: food animal production medicine. 3ra ed. Pensilvannia, United States, W.B. Saunders Company; 2003.

53. Moody DE, Pomp D, Barendse W. Restriction fragment length polymorphism in amplification products of the bovine PIT1 gene and assignment of PIT1 to bovine chromosome 1. Anim Genet. 1995 Feb;26(1):45-47. https://doi.org/10.1111/j.1365-2052.1995.tb02620.x

54. Spicer LJ. Leptin: a possible metabolic signal affecting reproduction. Domest Anim Endocrinolo. 2001 Nov;21(4):251-70. https://doi.org/10.1016/S0739-7240(01)00120-5 
55. Munoz-Gutierrez M, Findlay PA, Adam CL, Wax G, Campbell BK, Kendall NR, Scaramuzzi RJ. The ovarian expression of mRNAs for aromatase, IGF-I receptor, IGF-binding protein-2,-4 and-5, leptin and leptin receptor in cycling ewes after three days of leptin infusion. Reproduction. 2005 Dec;130(6):869-81. https://doi.org/10.1530/rep.1.00557

56. Nicklin LT, Robinson RS, Marsters P, Campbell BK, Mann GE, Hunter MG. Leptin in the bovine corpus luteum: receptor expression and effects on progesterone production. Mol. Reprod. Dev. 2007 Dec;74(6):724-9. https://doi.org/10.1002/mrd.20671

57. Ye Y, Kawamura K, Sasaki M, Kawamura N, Groenen P, Gelpke MDS. Tanaka T. Leptin and ObRa/MEK signalling in mouse oocyte maturation and preimplantation embryo development. Reprod. Biomed. [Internet]. 2009 [cite 2021 Mar 23];19(2):181-90. https://doi.org/10.1016/S1472-6483(10)60070-3

58. Craig J, Zhu H, Dyce PW, Petrik J, Li J. Leptin enhances oocyte nuclear and cytoplasmic maturation via the mitogen-activated protein kinase pathway. Endocrinology. 2004 May;145(11):5355-63. https://doi.org/10.1210/en.2004-0783

59. Boelhauve M, Sinowatz F, Wolf E, Paula-Lopes FF. Maturation of bovine oocytes in the presence of leptin improves development and reduces apoptosis of in vitro-produced blastocysts. Biol. Reprod. 2005 Oct;73:737-44. https://doi.org/10.1095/biolreprod.105.041103

60. Liefers SC, Veerkamp RF, Te Pas MFW, Chilliard Y, Van der Lende T. Genetics and physiology of leptin in periparturient dairy cows. Domest. Anim. Endocrinol. 2005 Jul;29(1):227-38. https://doi.org/10.1016/j.domaniend.2005.02.009.

61. Laksmi DI, Pemayun TG, Damriyasa I, Dharmawan NS. Administration of Leptin Increases the Level of Follicle Stimulating Hormone (FSH) and Development of Ovarian Follicles in Postpartum Anestrus of Bali Cattle. Bali Med J. 2016;5(2):69-73.

62. Laksmi DI, Pemayun TG, Damriyasa I, Dharmawan NS. Administration of Leptin Increased Concentration of Estrogen and Accelerate the Emergence of Estrus in Post Partum Anestrus of Bali Cattle. Glob Vet. 2016;17,4826. DOI: $10.15562 / \mathrm{bmj} . v 5 i 2.215$.

63. Wathes DC, Bourne N, Cheng Z, Mann GE, Taylor VJ, Coffey MP. Multiple correlation analyses of metabolic and endocrine profiles with fertility in primiparous and multiparous cows. J. Dairy Sci. 2007 Mar;90(3),1310-25. https://doi.org/10.3168/jds.S0022-0302(07)71619-3

64. Beam SW, Butler WR. Effects of energy balance on follicular development and first ovulation in postpartum dairy cows. J. Reprod. Fertil. Suppl. 1999;54:411-24.

65. Pushpakumara PGA, NH, Gardner CK, Reynolds DE, Wathes DC. Relationships between transition diet, metabolic parameters and fertility in lactating cows. Theriogenology. 2003;60(6):1165-85. https://doi.org/10.1016/S0093691X(03)00119-5

66. De Matteis G, Scatà M, Grandoni F, Petrera F, Abeni F, Catillo G, Moioli B. Association analyses of single nucleotide polymorphisms in the leptin and leptin receptor genes on milk and morphological traits in Holstein cows. Open J Anim Sci. 2012 Apr;2(3),174-82. http://dx.doi.org/10.4236/ojas.2012.23024

67. Musa SI. Computational Molecular Analysis of Bovine Luteinizing Hormone Receptor using Predict Protein. EAS J Biotechnol Genet. 2019 Feb;1(1):9-13.

2021 by the authors. Submitted for possible open access publication under the terms and conditions of the Creative Commons Attribution (CC BY NC) license (https://creativecommons.org/licenses/by-nc/4.0/). 